\title{
Late entry into HIV care: lessons from Brazil, 2003 to 2006
}

\author{
Alexandre Grangeiro ${ }^{1 *}$, Maria Mercedes Loureiro Escuder ${ }^{2 \dagger}$ and Julio Cesar Rodrigues Pereira ${ }^{3 \dagger}$
}

\begin{abstract}
Background: To ascertain the population rates and proportion of late entry into HIV care, as well as to determine whether such late entry correlates with individual and contextual factors.

Methods: Data for the 2003-2006 period in Brazil were obtained from public health records. A case of late entry into HIV care was defined as one in which HIV infection was diagnosed at death, one in which HIV infection was diagnosed after the condition of the patient had already been aggravated by AIDS-related diseases, or one in which the CD4 ${ }^{+}$T-cell count was $\leq 200$ cells $/ \mathrm{mm}^{3}$ at the time of diagnosis. We also considered extended and stricter sets of criteria (in which the final criterion was $\leq 350 \mathrm{cell} s / \mathrm{mm}^{3}$ and $\leq 100 \mathrm{cells} / \mathrm{mm}^{3}$, respectively). The estimated risk ratio was used in assessing the effects of correlates, and the population rates (per 100,000 population) were calculated on an annual basis.

Results: Records of 115,369 HIV-infected adults were retrieved, and $43.6 \%(50,358)$ met the standard criteria for late entry into care. Diagnosis at death accounted for 29\% $(14,457)$ of these cases. Late entry into HIV care (standard criterion) was associated with certain individual factors (sex, age, and transmission category) and contextual factors (region with less economic development/increasing incidence of AIDS, lower local HIV testing rate, and smaller municipal population). Use of the extended criteria increased the proportion of late entry by $34 \%$ but did not substantially alter the correlations analyzed. The overall population rate of late entry was 9.9/100,000 population, specific rates being highest for individuals in the 30-59 year age bracket, for men, and for individuals living in regions with greater economic development/higher HIV testing rates, collectively accounting for more than half of the cases observed.

Conclusions: Although the high proportion of late entry might contribute to spreading the AIDS epidemic in less developed regions, most cases occurred in large cities, with broader availability of HIV testing, and in economically developed regions.
\end{abstract}

Keywords: AIDS, Health policy, Late HIV diagnosis, Risk, Brazil

\section{Background}

The effectiveness of AIDS treatment programs is severely affected by the proportion of HIV-infected individuals who do not enter into clinical care in a timely manner (i.e., who enter late). This is because HIV-infected individuals who are under treatment are less likely to transmit the virus to others, not only because such individuals tend to adopt safe sex practices but also because the use of antiretroviral therapy (ART) can reduce the risk of

\footnotetext{
* Correspondence: ale.grangeiro@gmail.com

${ }^{\dagger}$ Equal contributors

${ }^{1}$ Departamento de Medicina Preventiva da Faculdade de Medicina da Universidade de São Paulo, São Paulo, Brazil

Full list of author information is available at the end of the article
}

sexual transmission of HIV by more than 90\% [1,2]. Late entry into care is also strongly associated with premature death among HIV-infected individuals [3-7], accounting for approximately $40 \%$ of all AIDS-related deaths [8]. Late entry into HIV care also has negative consequences for health care systems, increasing costs due to the medications and highly complex procedures required in order to treat individuals who are in the advanced stages of HIV infection when they enter treatment $[9,10]$. To minimize this problem, there have been numerous initiatives aimed at promoting early diagnosis and the initiation of clinical treatment in the early stages of infection [11-15], particularly through encouraging voluntary testing $[11,13,14]$ and by strengthening the cooperation

\section{Biomed Central}


between and among centers for the diagnosis and treatment of HIV-infected individuals [13,14]. Nevertheless, the proportion of individuals who have sought treatment late remains high-over $30 \%$ in high income countries [16-23] and over 70\% in African countries [9,24]. The main hindrances to the success of these initiatives are related to the individual $[12,13,25,26]$, the social context [25-27], and the way in which the health care services are organized [19,28-30].

Although differing in their methodological approaches [31], studies of late entry into HIV care have provided, for different contexts, a broad range of estimates of the proportion of such late entry and have identified different associated risk factors [16,19-23,32]. Therefore, there is a need for further knowledge about the absolute risk of late entry, both at the population level and in social segments exposed to certain risk factors (such as advanced age, male gender, and a low level of local economic development). In low- and middle-income countries, the proportion of individuals entering HIV care late has often been evaluated on the basis of the time at which ART is initiated, rather than the actual time of entry into care [24,33,34]. This strategy has two drawbacks. First, it ignores the fact that other therapeutic and prophylactic interventions should be undertaken prior to the initiation of ART. Second, the criterion for starting ART has changed over time, and there is a trend toward earlier prescription of ART. Therefore, when late entry into care is defined by the initiation of ART, it is difficult to make comparisons over time and across studies.

In a recent study [8], we evaluated data related to the overall population of $\mathrm{HIV}$-infected individuals who entered care in Brazil between 2003 and 2006, estimating the proportion of individuals entering late into care and the impact that this has on the rates of AIDS mortality. In the present study, we sought to analyze the demographic and epidemiological characteristics related to late entry, estimating the absolute and relative risk, which we calculated for that population as a whole and for different social segments, using various clinical and immunological parameters. We have also analyzed the proportional contribution of different social segments to the total number of individuals entering late into HIV care in Brazil.

\section{Methods}

To analyze the general population of HIV-infected individuals (over 15 years of age) who entered into care at public health care facilities in Brazil between 2003 and 2006, we obtained data from the information systems of the Brazilian National Ministry of Health. Specifically, we obtained data from the following: the Sistema de Controle de Exames Laboratoriais da Rede Nacional de Contagem de Linfócitos $C D 4^{+} / \mathrm{CD}^{+}$e Carga Viral
(SISCEL, Brazilian National CD4 ${ }^{+} / \mathrm{CD}^{+} \mathrm{T}$ Lymphocyte Count and Viral Load Network Laboratory Test Control System) database-for the initial CD $4^{+}$T-cell counts (the national guidelines in Brazil state that an initial CD4 ${ }^{+} \mathrm{T}-$ cell count must be obtained at time of entry into HIV care); the Sistema de Informação de Agravos de Notificação (SINAN, Disease Notification Information System)for information on the occurrence of AIDS-related diseases; the Sistema de Informação sobre Mortalidade (SIM, Mortality Information System) - for information on AIDS-related deaths (from death certificates); and the Departamento de Informática do Sistema Único de Saúde (DATASUS, Unified Health Care System Department of Information Technology)-for electronic records of treatment provided via the public health care system and contextual information on municipalities. The coverage of these systems ranges from $62.3 \%$ (SINAN) to $83 \%$ (SIM/SISCEL), as described in our earlier study [8], in which we also addressed the completeness of the data contained in the various databases.

To determine whether the databases employed included information on the maximum number of HIVinfected individuals entering into clinical treatment during the period under study, the SISCEL, SINAN, and SIM data were cross-referenced, by probabilistic record linkage, and the duplicate entries generated thereby were excluded [35]. The process of including cases in the study was described with a specific algorithm [8]. Cases in which data related to entry into care or mortality were incongruent were excluded from the analysis, as were those in which the initial CD4 ${ }^{+} \mathrm{T}$-cell count was delayed by more than six months, which would have misrepresented the initial immunological status.

A case of late entry into HIV care was typically defined as one in which HIV infection was diagnosed at death, one in which HIV infection was diagnosed after the condition of the patient had already been aggravated by AIDS-related diseases, or one in which the CD4 ${ }^{+}$T-cell count was $\leq 200$ cells $/ \mathrm{mm}^{3}$ at the time of diagnosis. Those were the standard criteria. In addition, we considered an extended set of criteria, in which the first two criteria were the same but the initial $\mathrm{CD}_{4}^{+} \mathrm{T}$-cell count was $\leq 350$ cells $/ \mathrm{mm}^{3}$, as well as a stricter set, in which the first two criteria were the same but the initial $\mathrm{CD}_{4}^{+}$ T-cell count was $\leq 100$ cells $/ \mathrm{mm}^{3}$. A case of HIV diagnosed at death was defined as a case in which the diagnosis was made within 20 days before death. The date of entry into care was defined as that of the earliest record found in any of the data sources. Data related to sex, age, and place of residence were collated into an analysis database, with the following hierarchy: SINAN, SIM, then SISCEL. The category of HIV transmission was obtained exclusively for AIDS cases reported to SINAN, because that information is not available in any 
of the other databases. We also analyzed contextual information (geopolitical region, HIV testing rate, and municipal population size), which were obtained from DATASUS.

Data were stratified by geopolitical region, because there are major differences among those regions in terms of human development, health care access, and trends in the AIDS epidemic. It has been shown that, in the northern and northeastern regions of Brazil, in comparison with the other regions of the country, there is a tendency toward an increase in the incidence of AIDS, the lowest per capita rates of medical visits, and the lowest per capita gross domestic product (GDP) [36].

The rate of HIV testing was assessed at the municipal level as the number of enzyme-linked immunosorbent assay and rapid tests performed at public health care facilities per thousand population in 2008. Based on these data, the HIV testing rate was categorized as follows: low ( $\leq 1 \mathrm{HIV}$ test/1,000 population); medium (between 1.01 and $10 \mathrm{HIV}$ tests/1,000 population); or high ( $>10 \mathrm{HIV}$ tests/1,000 population). The municipalities were categorized by population: $<100,000$ inhabitants; 100,000499,999 inhabitants; or $\geq 500,000$ inhabitants.

Five categories of HIV transmission were considered: through exclusively female-to-male sexual contact (in heterosexual men); through exclusively male-to-female sexual contact (in heterosexual women); through maleto-male or male-to-female sexual contact (in homosexual/bisexual men); through injection drug use; and through transfusion of blood or blood products. Individuals fitting more than one category of transmission were classified using the following hierarchy: recipients of blood transfusions; injection drug users; homosexual/ bisexual males; heterosexual individuals (males or females); and users of blood products.

The study protocol was approved by the Research Ethics Committee of the São Paulo State STD and AIDS Referral and Training Center, located in the city of São Paulo, Brazil. Because patient data were collected from the Brazilian Ministry of Health (NMH) national information systems and analyzed anonymously after the systems had been cross-referenced, informed consent was not necessary.

\section{Data analysis}

The proportion and population rates of late entry into HIV care were estimated for the standard, extended, and strict definitions. The distribution of those rates was examined by sex, age bracket, geopolitical region, and HIV testing rate. Population rates (per 100,000 population) were calculated on an annual basis, the denominator being the adult population at risk of late entry into HIV care. Individuals already under care at the beginning of a given year, and those in whom HIV had been diagnosed in a timely manner during that year, were not included in the annual denominator. The averages for the study period were used in the analyses.

Poisson regression with a log-link function was used in order to assess effect as risk ratios (RR) and the respective $95 \%$ confidence intervals (95\% CIs), using the standard late entry criteria as the reference. Individual and contextual variables with a $\mathrm{p}<0.05$ were included in the model, whereas those with a $\mathrm{p}<0.10$ were excluded. The category of HIV transmission was analyzed with a separate Poisson regression model.

The impact of the changes in the scenario resulting from the application of the three different sets of criteria (standard, strict and extended) was examined by determining the differences in magnitude of the proportions and in the profile (demographic and epidemiological characteristics) of the individuals included under each set of criteria.

\section{Results}

We identified 115,369 HIV-infected individuals who entered into care in Brazil between 2003 and 2006. Of those individuals, $56.3 \%$ were male, $66.0 \%$ were between 30 and 59 years of age, and $50.7 \%$ resided in the southeastern region of the country (Table 1 ). The annual number of new cases ranged from 24,487 (in 2003) to 31,941 (in 2005), and the annual average number of new patients for the entire period was 28,842 .

We excluded 18,638 (13.9\%) cases in which the initial $\mathrm{CD}^{+}{ }^{+}$T-cell count was obtained six months or more after entry into care, as well as $42(0.03 \%)$ cases in which the information related to the date of entry into care was inconsistent. The demographic characteristics of the excluded cases were similar to those of the cases included in the analysis [8].

\section{Proportion and relative risk of late entry into HIV care}

As can be seen in Table 1, the overall proportion of late entry into HIV care, according to the standard criterion, was 43.6\% (50,358 individuals) between 2003 and 2006. We detected a slight, but statistically significant, decrease between the first and last years of the period studied (from $43.5 \%$ to $41.6 \%, \mathrm{p}<0.001$ ).

Table 1 also shows that the relative risk of late entry into HIV care was highest for the $\geq 60$ year age bracket (RR: 1.91, 95\% CI: 1.85-1.98); for the northern and northeastern regions (RR: 1.33, 95\% CI: 1.29-1.37 and RR: 1.19, 95\% CI: 1.16-1.21, respectively); and for males (RR: 1.33, 95\% CI: 1.31-1.35). At the municipal level, lesser, but statistically significant, effects were observed for low HIV testing rate (RR: 1.09, 95\% CI: 1.06-1.11) and having $\leq$ 100,000 inhabitants (RR: 1.08, 95\% CI: 1.06-1.10).

Information on the HIV transmission category was available for 37,391 cases during the period under study. 
Table 1 Proportion of late entry into HIV care, as defined by the standard criterion, with adjusted risk ratios. Brazil (2003-2006)

\begin{tabular}{|c|c|c|c|c|c|c|c|c|c|}
\hline \multirow[t]{2}{*}{ Characteristic } & & \multirow[t]{2}{*}{$\mathrm{N}$} & \multirow[t]{2}{*}{$\%$} & \multirow[t]{2}{*}{$\begin{array}{l}\text { Proportion } \\
\text { of late entry }\end{array}$} & \multirow[t]{2}{*}{ Risk ratio } & \multirow[t]{2}{*}{$\begin{array}{l}\text { Adjusted } \\
\text { risk ratio }\end{array}$} & \multicolumn{2}{|c|}{$\begin{array}{l}95 \% \text { confidence } \\
\text { interval }\end{array}$} & \multirow[t]{2}{*}{$\mathrm{p}$} \\
\hline & & & & & & & Min & Max & \\
\hline Brazil & & 115,369 & 100 & 43.6 & - & - & - & - & - \\
\hline \multirow[t]{6}{*}{ Geopolitical region } & South & 22,229 & 19.3 & 40.8 & 1 & 1 & - & - & \\
\hline & North & 6,270 & 5.4 & 53.4 & 1.31 & 1.33 & 1.29 & 1.37 & $<0.001$ \\
\hline & Northeast & 17,448 & 15.1 & 48.1 & 1.18 & 1.19 & 1.16 & 1.21 & $<0.001$ \\
\hline & Central-West & 7,997 & 6.9 & 47.1 & 1.15 & 1.16 & 1.13 & 1.20 & $<0.001$ \\
\hline & Southeast & 58,499 & 50.7 & 43.1 & 1.06 & 1.05 & 1.03 & 1.07 & $<0.001$ \\
\hline & No data & 2,926 & 2.5 & & & & & & \\
\hline \multirow{4}{*}{$\begin{array}{l}\text { Size of municipality } \\
\text { (number of inhabitants) }\end{array}$} & $\geq 500,000$ & 46,835 & 40.6 & 42.6 & 1 & 1 & - & - & \\
\hline & $100,000-499,999$ & 33,339 & 28.9 & 43.0 & $1.01^{*}$ & 1.04 & 1.02 & 1.06 & $<0.001$ \\
\hline & $<100,000$ & 30,429 & 26.4 & 46.3 & 1.09 & 1.08 & 1.06 & 1.10 & $<0.001$ \\
\hline & No data & 4,766 & 4.1 & & & & & & \\
\hline \multirow[t]{4}{*}{ HIV testing rate ${ }^{\dagger}$} & High & 89,550 & 77.6 & 42.7 & 1 & 1 & - & - & \\
\hline & Medium & 5,063 & 4.4 & 46.8 & 1.10 & 1.06 & 1.03 & 1.10 & $<0.001$ \\
\hline & Low & 15,990 & 13.9 & 48.5 & 1.14 & 1.09 & 1.06 & 1.11 & $<0.001$ \\
\hline & No data* & 4,766 & 4.1 & & 1 & & & & \\
\hline \multirow[t]{3}{*}{ Sex } & Female & 50,354 & 43.6 & 35.7 & & 1 & - & - & \\
\hline & Male & 64,932 & 56.3 & 49.8 & 1.40 & 1.33 & 1.31 & 1.35 & $<0.001$ \\
\hline & No data & 83 & 0.1 & & & & & & \\
\hline \multirow[t]{3}{*}{ Age bracket } & $15-29$ years & 36,201 & 31.4 & 30 & 1 & 1 & - & - & \\
\hline & $30-59$ years & 76,134 & 66 & 49.5 & 1.65 & 1.60 & 1.58 & 1.63 & $<0.001$ \\
\hline & $\geq 60$ years & 3,034 & 2.6 & 59.3 & 1.98 & 1.91 & 1.85 & 1.98 & $<0.001$ \\
\hline \multirow{5}{*}{$\begin{array}{l}\text { HIV transmission } \\
\text { category }^{\S}\end{array}$} & Heterosexual women & 15,665 & 41.9 & - & 1 & 1 & - & - & \\
\hline & Injection drug user & 2,997 & 8.0 & - & 1.18 & 1.18 & 1.15 & 1.22 & $<0.001$ \\
\hline & Heterosexual men & 11,467 & 30.7 & - & 1.21 & 1.17 & 1.15 & 1.19 & $<0.001$ \\
\hline & Blood transfusion & 107 & 0.3 & - & 1.16 & 1.15 & 1.01 & 1.32 & 0.039 \\
\hline & Homosexual/bisexual men & 7,155 & 19.1 & - & 1.06 & 1.04 & 1.02 & 1.07 & $<0.001$ \\
\hline
\end{tabular}

${ }^{*}$ Not significant; ${ }^{\dagger} \mathrm{High}=>10$ tests/1,000 population, Medium = from 1.01 to 10 tests/1,000 population, Low = $\leq 1$ test/1,000 population; ${ }^{*}$ No information available on city of residence; ${ }^{\$}$ The categories of transmission were analyzed with a separate Poisson regression model, including the 37,391 individuals for whom information on transmission category was available. Control of confounding variables = region, HIV testing rate, and age. Population size was disregarded as a misleading variable as it did not show statistical significance in this regression model.

Of those, $41.9 \%$ were in heterosexual women, $30.7 \%$ were in heterosexual men, $19.1 \%$ were in homosexual/bisexual men, $8.0 \%$ were in injection drug users, and $0.3 \%$ were in individuals who had received transfusions of blood or blood products (Table 1). The highest risk ratios were found for injection drug users $(\mathrm{RR}=1.18$, 95\% CI: 1.15 1.22 ) and heterosexual men ( $R R=1.17,95 \% \mathrm{CI}: 1.15-1.19)$. Marginal risk ratios were observed for being a homosexual/bisexual men $(R R=1.04 ; 95 \% C I$ : $1.02-1.07)$ and for having received a blood transfusion $(\mathrm{RR}=1.15,95 \% \mathrm{CI}$ : 1.01-1.32).

As a corollary of the associations observed, the stratified analysis of the proportion of late entry into HIV care showed marked variation depending on the social segment analyzed (Table 2). The lowest proportion (about half of the national average) was among women in the 15-29 year age bracket residing in the southern or southeastern region of the country. Among such women, the proportions were $20.2 \%$ for those residing in the southern region and $22.2 \%$ for those residing in the southeastern region. For individuals (of either sex) in the $\geq 60$ year age bracket and residing in the northern, northeastern, and central-west regions of the country, the proportion was above $60 \%$.

\section{Population rate of late entry into HIV care}

The average population rate of late entry into HIV care observed for Brazil as a whole was 9.9 cases/100,000 population (Table 3). Regardless of sex and geopolitical region of residence, the average population rate was 
Table 2 Stratified analysis of the proportion of late entry into HIV care, as defined by standard and extended criteria, and percentage increase with the use of the extended criterion. Brazil (2003-2006)

\begin{tabular}{|c|c|c|c|c|c|c|c|c|c|c|c|c|}
\hline \multirow[t]{2}{*}{ Characteristic } & \multicolumn{4}{|c|}{ Female by age bracket } & \multicolumn{4}{|c|}{ Male by age bracket } & \multicolumn{4}{|c|}{ Total by age bracket } \\
\hline & $15-29$ & $30-59$ & $\geq 60$ & Total & $15-29$ & $30-59$ & $\geq 60$ & Total & $15-29$ & $30-59$ & $\geq 60$ & Total \\
\hline \multicolumn{13}{|c|}{ Standard criterion } \\
\hline Brazil & 23.1 & 42.9 & 55.1 & 35.7 & 37.6 & 53.9 & 61.9 & 49.8 & 30.0 & 49.5 & 59.3 & 43.6 \\
\hline \multicolumn{13}{|c|}{ Geopolitical region } \\
\hline North & 33.8 & 54.9 & 65.9 & 45.7 & 50.5 & 63.0 & 60.9 & 58.8 & 42.4 & 60.0 & 62.5 & 53.4 \\
\hline Northeast & 28.1 & 47.9 & 62.0 & 40.1 & 45.2 & 57.3 & 63.8 & 54.0 & 36.5 & 53.8 & 63.2 & 48.1 \\
\hline Central-West & 24.3 & 49.1 & 60.5 & 38.8 & 37.2 & 59.4 & 69.2 & 53.3 & 30.5 & 55.5 & 66.0 & 47.1 \\
\hline Southeast & 22.2 & 42.2 & 55.3 & 35.9 & 35.1 & 52.5 & 61.9 & 48.5 & 28.6 & 48.4 & 59.3 & 43.1 \\
\hline South & 20.2 & 38.8 & 50.6 & 31.4 & 36.0 & 54.0 & 62.0 & 49.5 & 26.6 & 47.6 & 57.6 & 40.8 \\
\hline \multicolumn{13}{|l|}{ HIV testing rate ${ }^{1}$} \\
\hline High & 22.5 & 42.0 & 54.9 & 35.1 & 36.2 & 52.6 & 61.3 & 48.5 & 29.2 & 48.4 & 58.8 & 42.7 \\
\hline Medium & 26.4 & 45.5 & 63.2 & 38.6 & 41.8 & 58.1 & 55.4 & 54.0 & 32.9 & 52.8 & 58.3 & 46.8 \\
\hline Low & 25.3 & 47.3 & 56.2 & 38.7 & 45.5 & 61.3 & 65.5 & 57.2 & 34.1 & 55.4 & 62.4 & 48.5 \\
\hline \multicolumn{13}{|c|}{ Extended criterion } \\
\hline Brazil & 39.4 & 58.5 & 66.8 & 51.5 & 52.4 & 68.1 & 75.6 & 64.1 & 45.6 & 64.3 & 72.2 & 58.6 \\
\hline \multicolumn{13}{|c|}{ Geopolitical region } \\
\hline North & 55.7 & 74.7 & 81.8 & 66.4 & 67.6 & 78.9 & 76.1 & 75.1 & 61.8 & 77.4 & 77.9 & 71.5 \\
\hline Northeast & 43.7 & 62.8 & 71.5 & 55.2 & 60.6 & 71.0 & 79.2 & 68.3 & 52.0 & 67.9 & 76.6 & 62.7 \\
\hline Central-West & 43.0 & 65.0 & 73.7 & 55.9 & 53.7 & 74.2 & 82.7 & 68.6 & 48.2 & 70.8 & 79.4 & 63.2 \\
\hline Southeast & 37.4 & 57.3 & 66.4 & 50.9 & 49.3 & 66.3 & 74.1 & 62.3 & 43.3 & 62.7 & 71.1 & 57.4 \\
\hline South & 37.9 & 56.7 & 65.4 & 49.1 & 51.7 & 69.1 & 78.1 & 64.8 & 43.5 & 63.9 & 73.2 & 57.3 \\
\hline \multicolumn{13}{|l|}{ HIV testing rate } \\
\hline High & 39.1 & 58.1 & 67.5 & 51.3 & 51.4 & 67.1 & 75.3 & 63.1 & 45.1 & 63.5 & 72.2 & 58.0 \\
\hline Medium & 42.2 & 61.0 & 73.7 & 54.2 & 56.0 & 72.7 & 66.2 & 68.4 & 48.1 & 67.7 & 68.9 & 61.7 \\
\hline Low & 41.8 & 61.9 & 66.4 & 53.9 & 60.5 & 74.4 & 80.0 & 70.8 & 49.9 & 69.1 & 75.5 & 62.9 \\
\hline \multicolumn{13}{|c|}{ Percentage increase with extended criterion } \\
\hline Brazil & 70.6 & 36.6 & 21.2 & 44.4 & 39.4 & 26.3 & 22.0 & 28.7 & 52.0 & 29.9 & 21.8 & 34.4 \\
\hline \multicolumn{13}{|c|}{ Geopolitical region } \\
\hline North & 65.1 & 36.1 & 24.1 & 45.3 & 33.9 & 25.2 & 25.0 & 27.7 & 45.8 & 28.8 & 24.6 & 33.9 \\
\hline Northeast & 55.5 & 31.1 & 15.3 & 37.7 & 34.1 & 23.9 & 24.3 & 26.3 & 42.5 & 26.4 & 21.2 & 30.4 \\
\hline Central-West & 77.4 & 32.4 & 21.8 & 44.1 & 44.4 & 25.1 & 19.5 & 28.7 & 58.0 & 27.6 & 20.3 & 34.2 \\
\hline Southeast & 68.5 & 35.5 & 20.1 & 41.8 & 40.5 & 26.3 & 19.7 & 28.7 & 51.4 & 29.5 & 19.9 & 33.2 \\
\hline South & 87.6 & 45.9 & 29.1 & 56.4 & 43.6 & 28.0 & 26.0 & 30.9 & 63.2 & 34.2 & 27.1 & 40.2 \\
\hline
\end{tabular}

${ }^{*} \mathrm{High}=>10$ tests/1,000 population; Medium = from 1.01 to 10 tests/1,000 population; Low $=\leq 1$ test/1,000 population.

found to be highest among individuals in the 30-59 year age bracket (15.5 cases/100,000 population), in which it was 5.3 times higher than was that found for those in the $\geq 60$ year age bracket (2.9/100,000 population).

The average population rates of late entry into HIV care tended to rise in parallel with regional increases in per capita GDP and in parallel with regional decreases in the incidence of AIDS. Consequently, the average rate was highest in the southern region $(11.8 / 100,000$ population) and lowest in the northeastern region $(6.2 / 100,000$ population.
The population rate of late entry into HIV care tended to decrease in parallel with that of HIV testing rates. This tendency was observed systematically in all of the social segments studied. In cities, where HIV testing rates are higher, the population rate of late entry into HIV care (12.1/100,000 population) was $22 \%$ higher than the national average. As a corollary of this population rate tendency, the largest proportions of individuals entering late into HIV care were in areas where the HIV testing rate was highest, were in the 30-59 year age bracket, were male, and resided in certain geopolitical 
Table 3 Population rates* of late entry into HIV care (100,000 population), as defined by standard and extended criteria. Brazil (2003-2006)

\begin{tabular}{|c|c|c|c|c|c|c|c|c|c|c|c|c|}
\hline \multirow[t]{2}{*}{ Characteristics } & \multicolumn{4}{|c|}{ Female by age bracket } & \multicolumn{4}{|c|}{ Male by age bracket } & \multicolumn{4}{|c|}{ Total by age bracket } \\
\hline & 15 to 29 & 30 to 59 & $\geq 60$ & Total & 15 to 29 & 30 to 59 & $\geq 60$ & Total & 15 to 29 & 30 to 59 & $\geq 60$ & Total \\
\hline \multicolumn{13}{|c|}{ Standard criterion } \\
\hline Brazil & 4.4 & 10.5 & 1.8 & 7.0 & 6.5 & 21.3 & 4.1 & 13.3 & 5.3 & 15.5 & 2.9 & 9.9 \\
\hline \multicolumn{13}{|c|}{ Geopolitical region } \\
\hline North & 4.5 & 9.9 & 1.8 & 6.6 & 7.1 & 18.5 & 3.5 & 11.8 & 5.8 & 14.3 & 2.7 & 9.2 \\
\hline Northeast & 2.8 & 6.5 & 0.9 & 4.2 & 4.5 & 13.9 & 2.2 & 8.3 & 3.7 & 10.0 & 1.5 & 6.2 \\
\hline Central-West & 4.6 & 10.6 & 2.7 & 7.3 & 6.6 & 22.1 & 5.6 & 13.9 & 5.6 & 16.3 & 4.1 & 10.6 \\
\hline Southeast & 4.3 & 11.7 & 2.2 & 7.7 & 6.8 & 23.5 & 4.9 & 14.8 & 5.5 & 17.4 & 3.4 & 11.1 \\
\hline South & 6.4 & 11.6 & 2.2 & 8.4 & 7.7 & 23.1 & 5.2 & 15.3 & 7.0 & 17.2 & 3.5 & 11.8 \\
\hline \multicolumn{13}{|l|}{ HIV testing rate ${ }^{\S}$} \\
\hline High & 5.2 & 12.4 & 2.3 & 8.3 & 8.1 & 26.2 & 5.5 & 16.7 & 6.5 & 18.7 & 3.8 & 12.1 \\
\hline Medium & 4.4 & 9.9 & 1.7 & 6.7 & 5.2 & 18.0 & 2.7 & 11.0 & 4.6 & 13.8 & 1.9 & 8.6 \\
\hline Low & 2.3 & 5.3 & 0.7 & 3.5 & 3.1 & 9.6 & 1.7 & 5.9 & 2.6 & 7.4 & 1.2 & 4.6 \\
\hline \multicolumn{13}{|c|}{ Extended criterion } \\
\hline Brazil & 7.2 & 14.1 & 2.3 & 9.9 & 8.8 & 26.4 & 5.1 & 16.8 & 8.0 & 20.0 & 3.6 & 13.2 \\
\hline \multicolumn{13}{|c|}{ Geopolitical region } \\
\hline North & 7.4 & 13.5 & 2.3 & 9.6 & 9.4 & 23.2 & 4.4 & 15.0 & 8.4 & 18.5 & 3.4 & 12.3 \\
\hline Northeast & 4.4 & 8.5 & 1.1 & 5.8 & 6.0 & 17.2 & 2.7 & 10.5 & 5.2 & 12.6 & 1.8 & 8.1 \\
\hline Central-West & 8.1 & 14.0 & 3.3 & 10.5 & 9.5 & 27.7 & 6.7 & 17.9 & 8.8 & 20.8 & 5.0 & 14.2 \\
\hline Southeast & 7.2 & 15.9 & 2.6 & 10.9 & 9.5 & 29.6 & 5.9 & 19.1 & 8.4 & 22.5 & 4.0 & 14.8 \\
\hline South & 11.9 & 16.9 & 2.8 & 13.2 & 11.1 & 29.6 & 6.6 & 20.0 & 11.5 & 23.1 & 4.5 & 16.5 \\
\hline \multicolumn{13}{|l|}{ HIV testing rate ${ }^{\S}$} \\
\hline High & 8.7 & 16.8 & 3.0 & 11.9 & 11.3 & 33.0 & 7.0 & 21.4 & 10.0 & 24.5 & 4.7 & 16.5 \\
\hline Medium & 6.8 & 13.4 & 1.6 & 9.3 & 6.6 & 22.2 & 2.9 & 13.6 & 6.7 & 17.7 & 2.2 & 11.4 \\
\hline Low & 3.7 & 7.0 & 0.9 & 4.8 & 4.0 & 11.4 & 2.2 & 7.1 & 3.8 & 9.2 & 1.5 & 6.0 \\
\hline
\end{tabular}

*Average for 2003 to 2006 .

${ }^{\S}$ High $=>10$ tests/1,000 population; Medium $=$ from 1.01 to 10 tests $/ 1,000$ population; Low $=\leq 1$ test/1,000 population.

regions (those with a higher GDP and a decreasing incidence of AIDS), accounting for $79.1 \%, 74.9 \%, 64.2 \%$, and $50.6 \%$, respectively, of all cases of late entry into HIV care between 2003 and 2006 (Figure 1).

\section{Stricter and extended criteria}

When late entry into HIV care was defined according to the stricter criterion (Table 4), there were 34,088 cases (29.5\% of all reported cases). Of those, 19,631 (17.0\% of all

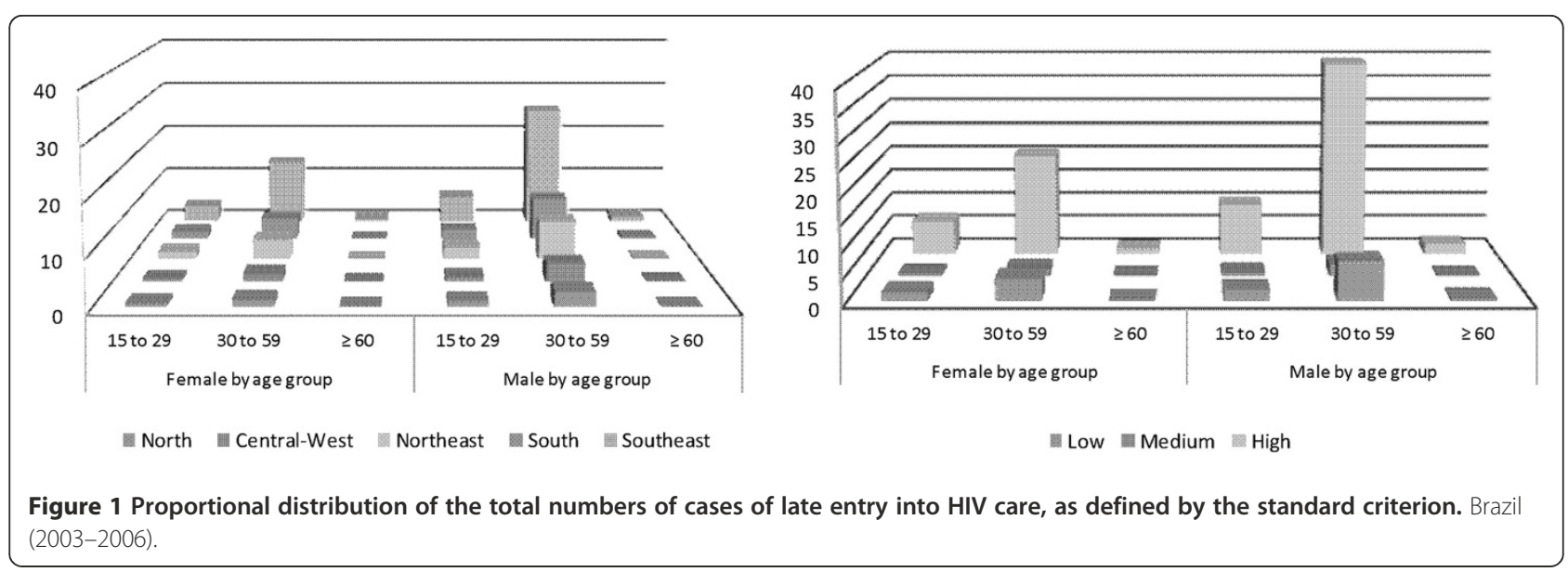


Table 4 Proportion of late entry into HIV care, as defined by the stricter criterion. Brazil (2003-2006)

\begin{tabular}{|c|c|c|c|c|c|c|c|c|c|c|c|c|}
\hline \multirow[t]{2}{*}{ Characteristics } & \multicolumn{4}{|c|}{ Female by age bracket } & \multicolumn{4}{|c|}{ Male by age bracket } & \multicolumn{4}{|c|}{ Total by age bracket } \\
\hline & $15-29$ & $30-59$ & $\geq 60$ & Total & $15-29$ & $30-59$ & $\geq 60$ & Total & $15-29$ & $30-59$ & $\geq 60$ & Total \\
\hline Brazil & 13.9 & 28.7 & 37.6 & 23.3 & 25.2 & 37.4 & 44.8 & 34.4 & 19.3 & 33.9 & 42.1 & 29.5 \\
\hline \multicolumn{13}{|c|}{ Geopolitical region } \\
\hline North & 20.0 & 35.5 & 38.6 & 28.6 & 34.8 & 44.2 & 44.6 & 41.1 & 27.6 & 40.9 & 42.6 & 35.9 \\
\hline Northeast & 18.6 & 33.7 & 40.9 & 27.7 & 31.8 & 41.6 & 44.2 & 38.8 & 25.1 & 38.6 & 43.0 & 34.1 \\
\hline Central-West & 14.0 & 32.5 & 40.8 & 24.8 & 24.2 & 40.3 & 47.4 & 35.8 & 18.9 & 37.4 & 45.0 & 31.2 \\
\hline Southeast & 12.9 & 28.6 & 39.6 & 23.7 & 23.3 & 36.3 & 47.3 & 33.4 & 18.1 & 33.2 & 44.3 & 29.3 \\
\hline South & 11.7 & 24.3 & 31.2 & 19.2 & 23.1 & 36.3 & 41.0 & 33.0 & 16.4 & 31.3 & 37.2 & 26.4 \\
\hline
\end{tabular}

reported cases) had met the criterion on the basis of the initial CD4 ${ }^{+}$T-cell count, and 14,457 (12.5\% of all reported cases) were cases of diagnosis at death. Individuals in whom late entry was classified according to the stricter criterion accounted for $67.7 \%$ of those in whom it was classified according to the standard criterion. Among those in whom late entry was classified according to the stricter criterion, there was a predominance of men, individuals in the $\geq 60$ year age bracket, and individuals residing in certain geopolitical regions (those with a lower GDP and an increasing incidence of AIDS).

When late entry into HIV care was defined according to the extended criterion (Table 2), there were 67,615 cases (58.6\% of all reported cases). The proportions were highest among residents of the geopolitical regions with a lower GDP and an increasing incidence of AIDS, especially among men in the 30-59 year age bracket, as well as among men and women in the $\geq 60$ year age bracket. In those social segments, the proportions were approximately $80 \%$ when the extended criterion was applied.

In comparison with late entry classified according to the standard criterion, the use of the extended criterion resulted in the inclusion of an additional 17,257 individuals (a 34.4\% increase). The largest proportional increase (of over $70 \%$ ) was observed among the population segments with the lowest proportion of late entry into HIV care when the standard criterion was applied, among which there was a predominance of women in the 15-29 year age bracket, especially in the geopolitical regions with a higher GDP and a decreasing incidence of AIDS.

When the stricter, standard, and extended criteria were compared in terms of the relative risk, the only differences observed were in the magnitude of the risk ratio, which trended discretely higher for the stricter criterion and discretely lower for the extended criterion. In addition, the categories presenting a marginal association when the standard criterion was applied lost their significance when the extended criterion was applied. That was especially true for the southeastern region, for municipalities with 100,000-499,999 inhabitants, and for being a homosexual/ bisexual man (Table 5).

\section{Discussion}

Because the Brazilian information systems provide consistent data on cases of HIV infection, it has been possible to increase our knowledge of aspects that are rarely discussed in the literature. A particular concern is the lack of information regarding late entry into HIV care in middle-income countries. The results of the present study show that, in Brazil, at least 2 out of every 5 HIV-infected individuals entered late into care between 2003 and 2006. Of those, approximately 70\% presented with severe clinical and immunological impairment, of whom approximately $30 \%$ were diagnosed only at death. In addition, the application of the extended criterion (i. e., the inclusion of individuals with an initial $\mathrm{CD}_{4}^{+} \mathrm{T}$-cell count $\leq 350$ cells $/ \mathrm{mm}^{3}$ ) increased the number of individuals entering late into HIV care by approximately one third. Therefore, approximately 6 out of every 10 HIVinfected individuals who entered into care in Brazil did so without having the opportunity to receive ART when it would have been most effective, resulting in less protection against new cases of infection in others and potentially higher nationwide rates of AIDS progression and mortality $[1,2,8]$. Such elevated rates could be responsible for the lack of advances in policies aimed at combating AIDS between 2000 and 2010, a period during which the absolute and relative numbers of AIDS cases increased [37].

Taking as our point of reference the proportion of late entry into HIV care when the standard criterion was applied, we found that Brazil is in an intermediate position in comparison with other countries. Lower proportions have been reported for high-income countries and regions, such as Northern France and Brussels (31.3\% in the 1997-2007 period) [16]; New Zealand (32.0\% in the 2005-2009 period) [23]; the United Kingdom and Ireland (33.4\% in 2003) [19]; the United States (36.4\% in 2005) [22]; Barcelona (38.5\% in the 2001-2009 period) [21]; and Italy (39.2\% in the 1997-2000 period) [18]. However, higher proportions have been reported for lowand middle-income countries. In a cohort study involving 36,000 patients in 12 countries [24], the collective proportions were $77 \%$ for the countries in Africa, $78 \%$ for 
Table 5 Proportion of late entry into HIV care, as defined by the extended and stricter criteria, with adjusted risk ratios. Brazil (2003-2006)

\begin{tabular}{|c|c|c|c|c|c|c|c|c|c|}
\hline \multirow[t]{3}{*}{ Characteristic } & & \multicolumn{4}{|c|}{ Extended Criterion } & \multicolumn{4}{|c|}{ Stricter Criterion } \\
\hline & & \multirow[t]{2}{*}{$\begin{array}{l}\text { Adjusted } \\
\text { risk ratio }\end{array}$} & \multicolumn{2}{|c|}{$\begin{array}{c}95 \% \text { Confidence } \\
\text { interval }\end{array}$} & \multirow[t]{2}{*}{$p$} & \multirow[t]{2}{*}{$\begin{array}{l}\text { Adjusted } \\
\text { risk ratio }\end{array}$} & \multicolumn{2}{|c|}{$\begin{array}{c}95 \% \text { Confidence } \\
\text { interval }\end{array}$} & \multirow[t]{2}{*}{$p$} \\
\hline & & & Min & Max & & & Min & Max & \\
\hline \multirow[t]{5}{*}{ Geopolitical Region } & South & 1 & - & - & - & 1 & - & - & - \\
\hline & North & 1.26 & 1.23 & 1.28 & $<0.001$ & 1.41 & 1.35 & 1.47 & $<0.001$ \\
\hline & Northeast & 1.10 & 1.08 & 1.11 & $<0.001$ & 1.30 & 1.26 & 1.34 & $<0.001$ \\
\hline & Central-West & 1.11 & 1.08 & 1.13 & $<0.001$ & 1.20 & 1.14 & 1.24 & $<0.001$ \\
\hline & Southeast & 1.00 & 0.98 & 1.01 & 0.498 & 1.11 & 1.08 & 1.13 & $<0.001$ \\
\hline \multirow{3}{*}{$\begin{array}{l}\text { Size of municipality } \\
\text { (number of inhabitants) }\end{array}$} & $\geq 500,000$ & 1 & - & - & - & 1 & - & - & \\
\hline & $100,000-499,999$ & 1.01 & 1.00 & 1.02 & 0.194 & 1.07 & 1.05 & 1.09 & $<0.001$ \\
\hline & $<100,000$ & 1.02 & 1.01 & 1.04 & 0.005 & 1.10 & 1.07 & 1.13 & $<0.001$ \\
\hline \multirow[t]{3}{*}{ HIV testing rate ${ }^{\dagger}$} & High & 1 & - & - & - & 1 & - & - & - \\
\hline & Medium & 1.05 & 1.03 & 1.08 & $<0.001$ & 1.11 & 1.06 & 1.16 & $<0.001$ \\
\hline & Low & 1.07 & 1.05 & 1.09 & $<0.001$ & 1.11 & 1.08 & 1.15 & $<0.001$ \\
\hline \multirow[t]{2}{*}{ Sex } & Female & 1 & - & - & - & 1 & - & - & - \\
\hline & Male & 1.20 & 1.19 & 1.21 & $<0.001$ & 1.40 & 1.37 & 1.42 & $<0.001$ \\
\hline \multirow[t]{3}{*}{ Age } & $15-29$ years & 1 & - & - & - & 1 & - & - & - \\
\hline & $30-59$ years & 1.39 & 1.37 & 1.40 & $<0.001$ & 1.70 & 1.66 & 1.74 & $<0.001$ \\
\hline & $\geq 60$ years & 1.56 & 1.52 & 1.60 & $<0.001$ & 2.10 & 2.00 & 2.20 & $<0.001$ \\
\hline \multirow[t]{5}{*}{ HIV Category of transmission $\$$} & Heterosexual women & 1 & - & - & - & 1 & - & - & - \\
\hline & Injection drug user & 1.07 & 1.05 & 1.09 & $<0.001$ & 1.15 & 1.09 & 1.21 & $<0.001$ \\
\hline & Heterosexual man & 1.08 & 1.07 & 1.09 & $<0.001$ & 1.15 & 1.12 & 1.19 & $<0.001$ \\
\hline & Blood transfusion & 1.11 & 1.03 & 1.19 & 0.004 & 0.96 & 0.73 & 1.27 & 0.793 \\
\hline & Homosexual/bisexual male & 1.01 & 0.99 & 1.02 & $<0.203$ & 1.00 & 0.96 & 1.04 & $<0.001$ \\
\hline
\end{tabular}

${ }^{\dagger} \mathrm{High}=>10$ tests/1,000 population; Medium $=$ from 1.01 to 10 tests/1,000 population; Low $=\leq 1$ test/1,000 population. ${ }^{\S}$ The categories of transmission were analyzed with a separate Poisson regression model, including the 37,391 individuals for whom information on transmission category was available. Control of confounding variables = region, HIV testing rate, and age. Population size was disregarded as a misleading variable as it did not show statistical significance in this regression model.

the countries in Asia, and 51\% for the countries in South America. Proportions higher than that observed in Brazil have also been reported for Thailand $(55 \%$ for the 2003-2004 period) [32] and for Vietnam (58.3\% for the 2004-2005 period) [38]. In Brazil, the reported proportion of late entry into HIV care has ranged from $42 \%$ in a nationwide study defining entry into care as the initiation of ART [34] to $68 \%$ in a study evaluating outpatients in the Brazilian state of Minas Gerais [33]. Comparisons across studies should be undertaken with caution, because different researchers adopt different definitions of late entry and evaluate different populations [31].

It is of note that we have combined a population-based risk assessment (based on population rates of late entry into HIV care) with a relative risk assessment (based on proportions and risk ratios for such late entry). Using this approach, we obtained results that differ, in many aspects, from those reported in the literature [16,19$23,32,38]$. One such discrepancy is the fact that, when analyzing the population-based risk (assessed by late entry rate), we found that, for individuals in the 30-59 year age bracket residing in geopolitical regions with a higher GDP, a decreasing incidence of AIDS, and the highest HIV testing rates, the risk of late entry into HIV care was 35\% higher than the national average, despite the lower relative risk and lower proportions of late entry found for that same group. Such individuals accounted for approximately $70 \%$ of the total number of cases of late entry in Brazil between 2003 and 2006. These results can be understood within the context of the fact that the population-based risk varied depending on the prevalence of HIV/AIDS within the country. Therefore, the geopolitical regions and social segments most affected by the epidemic [36] and in which the number of HIV-Infected individuals was highest tended to present the highest absolute risks and the highest numbers of cases of late entry into care, regardless of the proportion of late entry observed for those groups and regions. 
The advantage of using a approach in which the point of reference is the absolute risk is that it adds a public health perspective to the knowledge gathered to date regarding late entry into HIV care. If this new knowledge is applied, public policies designed to promote the early diagnosis of HIV infection will be more effective in reducing the number of cases of late entry into care, because they will prioritize the social segments and geopolitical regions in which the population rates of late entry are highest.

Analyses of relative risk (based on risk ratios) can facilitate the identification of social segments in which there are disproportionately large concentrations of cases of late entry into HIV care, as well as promoting the understanding of the factors that increase the probability of such late entry. Using such analyses, we observed that an increase in the proportion of late entry was independently associated with social differences (gender differences, generational differences, differences in sexual practices, and differences in terms of injection drug use), as well as contextual differences (related to the level of economic development and access to HIV testing at public health care facilities).

Our results, in terms of the social differences, are in agreement with those of studies conducted in other regions of the world [16,19-23,32], which have reported that the probability of late entry into HIV care is highest among older individuals, men (especially heterosexual men), and injection drug users. These findings can be explained by the social and cultural aspects of the AIDS epidemic $[13,26]$ and by the barriers to health care access $[18,19,27]$. Therefore, late entry into HIV care tends to take on added importance in individuals who are not recognized as being at risk of HIV infection or who do not perceive themselves to be at such risk, such as older individuals [20,21]; individuals in whom the rates of treatment seeking are low, such as men [16,38]; and individuals who are socially marginalized, such as injection drug users [16,19,21]. In Brazil, this inequality is evidenced, in part, by HIV testing rates. In a homebased study conducted in Brazil in 2005 [39], the social segments in which the HIV testing rate was found to be lowest among men (28\%) and among individuals $\geq 45$ years of age $(21 \%)$, whereas that rate was above the national average (of 34\%) among women (38\%), especially among those in the $25-34$ year age bracket $(60 \%)$. This is primarily attributable to prenatal HIV testing. Among homosexual men, the HIV testing rate was found to be below 60\% [39].

In terms of the contextual factors analyzed, we found that a higher HIV testing rate translated to a lower proportion of late entry. This is underscored by the fact that, during the period evaluated, a $5 \%$ increase in the rates of HIV testing [40] was paralleled by the $4.6 \%$ reduction we observed in the proportion of late entry. That same relationship has been evaluated in studies investigating the effectiveness and cost-effectiveness of HIV testing $[15,41,42]$, which have also shown that an increase in the availability of HIV testing corresponds to a higher rate of timely diagnosis and longer life expectancy of HIV-infected individuals.

The differences observed among municipalities of different population sizes, in terms of the proportion of late entry into HIV care, might reflect differences in the ease of access to HIV diagnosis and treatment, which tends to be restricted in smaller municipalities, where there are fewer HIV testing centers, it is more difficult to guarantee anonymity, and the social stigma associated with AIDS is often greater.

The association found between late entry into HIV care and geopolitical region with a lower GDP/increasing incidence of AIDS might indicate a two-fold relationship: a lower level of economic development creates barriers to health care access, increasing the proportion of late entry, which is, in turn, a major cause of the increase in the rate of new cases of HIV infection. This possible vicious cycle is a challenge for health care policy makers, and the promotion of early diagnosis in such regions might be an inflection point for improving our control of the epidemic.

Another important aspect of the present study was the application of three different criterion for defining late entry into HIV care. This approach allowed us to depict entry into care at the various stages in the evolution of HIV infection. Some initiatives have attempted to achieve a consensus regarding late entry into HIV care, with the objectives of increasing comparability across studies and implementing strategies of epidemiological surveillance of such late entry. In one such initiative [31], "late presentation" and "presentation with advanced HIV disease" were defined in a manner similar to that of the extended and standard criteria, respectively, employed in the present study. One advantage of using multiple criteria to define late entry was that it allowed us to characterize the contingent of HIV-infected individuals who are more likely to die because of such late entry, as occurred in nearly a third of those who were in the advanced stages of HIV infection upon entry into care. In addition, using multiple sets of criteria, we were able to highlight the potential lost opportunities to prevent new infections in others and to slow the advance of the AIDS epidemic, through the timely initiation of ART $[1,2]$, as occurred in nearly a two thirds of all HIVinfected individuals who began to receive ART later than recommended. If we further extended the criterion to include individuals with $\mathrm{CD}^{+}{ }^{+}$T-cell counts of 350-500 cells $/ \mathrm{mm}^{3}$, the magnitude of these losses would be even greater, because the use of ART at that stage of infection 
could reduce sexual HIV transmission by $90 \%$ and the incidence of AIDS-related diseases by $40 \%$ [2].

It is noteworthy that we found not substantial statistical differences between the use of each of these distinct criteria in terms of the individual and contextual factors that led to an increase in the proportion of late entry, whether analyzed on the basis of relative risk or on the basis of population rates. Therefore, it seems unnecessary to make major changes in the policies guidelines designed to promote timely access to the diagnosis and treatment of HIV infection specifically for individuals at a given clinical stage of infection.

The results we obtained by applying different sets of criteria for defining late entry in HIV care provide evidence of the need to establish precise parameters for access to ART, based on the stage of the infection, especially in countries where there are insufficient supplies of antiretroviral drugs, in order to achieve a balance between the benefits of early initiation of ART in asymptomatic individuals $[2,43,44]$ and the logic of prioritizing the treatment of AIDS patients in whom the risk of death is elevated because of greater clinical and immunological severity $[4,6,8]$. Although the ability of ART to reduce the transmission of HIV is well known [1,2], it should be borne in mind that the principal objective of ART is to improve the quality of life of HIV-infected individuals. In addition, there is no consistent evidence that the HIV/AIDS epidemic can be controlled through biomedical interventions [45].

The results obtained in the present study should be interpreted within the limits of its data and analysis, which were described in a previous study [8], in which we also analyzed the potential effects of excluding individuals in whom $\mathrm{CD}^{+}$T-cell counts were not obtained within the first six months after diagnosis. One significant limitation of the present study is the use of secondary data, which should not be taken at face value. The categories of HIV transmission require cautious interpretation, because we analyzed only the patients who progressed to AIDS, who could have characteristics that are different from those of individuals in the earlier stages of the disease. The purpose of including transmission categories here was to compensate for the lack of such information in other studies, especially in those conducted in low- or middle-income countries. Nevertheless, this study allowed us a glimpse into the complexity of late entry into HIV care, considering different criteria of classification and risk assessment. The results indicate a need to strengthen policies for timely diagnosis of HIV infection and alert us to the fact that, without changes in the proportion of late entry into HIV care, the epidemic is likely to be aggravated in less developed regions and in those with limited access to health care.

\section{Competing interests}

The authors declare that they have no competing interests.

\section{Acknowledgements}

This research was supported the National AIDS and Sexually-Transmitted Diseases Program of the Brazilian Ministry of Health, the Brasilien - Deutsche Gesellschaft für Technische Zusammenarbeit (GTZ Brazil, German Society for Technical Cooperation in Brazil), and the Fundação de Amparo à Pesquisa do Estado de São Paulo (FAPESP, São Paulo Research Foundation; Grant no. 2009/53692-1)

\section{Author details}

${ }^{1}$ Departamento de Medicina Preventiva da Faculdade de Medicina da Universidade de São Paulo, São Paulo, Brazil. ${ }^{2}$ Instituto de Saúde. Secretaria de Estado da Saúde de São Paulo, São Paulo, Brazil. ${ }^{3}$ Departamento de Epidemiologia da Faculdade de Saúde Pública da Universidade de São Paulo, São Paulo, Brazil.

\section{Authors' contributions}

AG, MME and JCRP participated in the design of the study and performed the analysis. All authors read and approved the final manuscript.

Received: 31 July 2011 Accepted: 24 April 2012

Published: 24 April 2012

\section{References}

1. Donnell D, Baeten JM, Kiarie J, Thomas KK, Stevens W, Cohen CR, et al: Heterosexual HIV-1 transmission after initiation of antiretroviral therapy: a prospective cohort analysis. Lancet 2010, 375(9731):2092-2098.

2. Cohen MS, Chen YQ, McCauley M, Gamble T, Hosseinipour MC, Kumarasamy $\mathrm{N}$, et al: Prevention of HIV-1 infection with early antiretroviral therapy. N Engl J Med 2011, 365:493-505.

3. Harrison KM, Song R, Zhang X: Life expectancy after HIV diagnosis based on national HIV surveillance data from 25 states, United States. J Acquir Immune Defic Syndr 2010, 53(1):124-130.

4. Tuboi SH, Schechter M, McGowan CC, Cesar C, Krolewiecki A, Cahn P, et al: Mortality during the first year of potent antiretroviral therapy in HIV-1infected patients in 7 sites throughout Latin America and the Caribbean. J Acquir Immune Defic Syndr 2009, 51(5):615-623.

5. Lawn SD, Little F, Bekker LG, Kaplan R, Campbel E, Orrell C, et al: Changing mortality risk associated with CD4 cell response to antiretroviral therapy in South Africa. AIDS 2009, 23(3):335-342.

6. Egger M, May M, Chêne G, Phillips AN, Ledergerber B, Dabis F, et al: Prognosis of HIV-1-infected patients starting highly active antiretroviral therapy: a collaborative analysis of prospective studies. Lancet 2002, 360 (9327):119-129 [Erratum in: Lancet 2002;360(9340):1178.].

7. Chasombat S, McConnell MS, Siangphoe U, Yuktanont $P$, Jirawattanapisal T, Fox K, et al: National expansion of antiretroviral treatment in Thailand, 2000-2007: program scale-up and patient outcomes. J Acquir Immune Defic Syndr 2009, 50(5):506-512.

8. Grangeiro A, Escuder MM, Menezes PR Alencar R, Ayres De Castilho E: Late entry into HIV care: estimated impact on AIDS mortality rates in Brazil, 2003-2006. PLos One 2011, 6(1):14585.

9. Krentz HB, Auld MC, Gill MJ: The high cost medical care for patients who present late (CD4 < 200 cells/microL) with HIV infection. HIV Med 2004, 5 (2):93-98.

10. Fleishman JA, Yehia BR, Moore RD, Gebo KA: HIV Research Network. The economic burden of late entry into medical care for patients with HIV infection. Med Care 2010, 48(12):1071-1079.

11. Bartlett JG, Branson BM, Fenton K, Hauschild BC, Miller V, Mayer KH: Opt-out testing for human immunodeficiency virus in the United States: progress and challenges. JAMA 2008, 300(8):945-951.

12. Obermeyer $C M$, Osborn M: The utilization of testing and counseling for HIV: a review of the social and behavioral evidence. Am J Public Heath 2007, 97(10):1762-1774.

13. Yazdanpanah Y, Lange J, Gerstoft J, Cairns G: Earlier testing for HIV - how do we prevent late presentation? Antiviral Therapy 2010, 15(suppl 1):17-24.

14. World Health Organization. HIV/AIDS. Towards universal access: Scaling up priority HIV/AIDS interventions in the health sector. Progress report 2010. Geneva: World Health Organization; 2010. Available from: http://whqlibdoc.who.int/ publications/2010/9789241500395_eng.pdf. Accessed in 2011 (Jun 11). 
15. Paltiel AD, Weinstein MC, Kimmel AD, Seage GR 3rd, Losina E, Zhang $H$, et al: Expanded screening for HIV in the United States-an analysis of costeffectiveness. N Engl J Med 2005, 352(6):586-595.

16. Nadiaye B, Salleron J, Vincent A, Bataille P, Bonnevie F, Choisy P, et al: Factors associated with presentation to care with advanced HIV disease in Brussels and Northern France. BMC Infectious Diseases 2011, 11:11.

17. Althoff KN, Gange SJ, Klein MB, Brooks JT, Hogg RS, Bosch RJ, et al: Late presentation for human immunodeficiency virus care in the United States and Canada. Clin Infect Dis 2010, 50(11):1512-1520.

18. Girardi E, Aloisi MS, Arici C, Pezzotti P, Serraino D, Balzano R, et al: Delayed presentation and late testing for HIV: demographic and behavioral risk factors in a multicenter study in Italy. J Acquir Immune Defic Syndr 2004, 36 (4):951-959.

19. Sullivan AK, Curtis H, Sabin CA, Johnson MA: Newly diagnosed HIV infections: review in UK and Ireland. BMJ 2005, 330(7503):1301-1302.

20. Zoufaly A, Heiden M, Marcus U, Hoffmann C, Stellbrink HJ, Voss L, et al. Late presentation for HIV diagnosis and care in Germany. HIV Medicine 2011. DOI: 10.1111/j.1468-1293.2011.00958.x

21. de Olalla PG, Mazardo C, Sambeat MA, Acaña I, Knobel H, Humet V, et al: Epidemiological characteristics and predictors of late presentation of HIV infection in Barcelona (Spain) during 2001-2009. AlDS Research and Therapy 2011, 8:22.

22. Centers for Disease Control for Prevention (CDC). Late HIV testing - 34 states, 1996-2005. MMWR Morb Mortal Wkly Rep 2009; 58(24):661-665.

23. Dickson NP, McAllister S, Sharples K, Paul C. Late presentation of HIV infection among adults in New Zealand: 2005-2010. HIV Medicine 2011. DOI: 10.1111/j.1468-1293.2011.00959.x

24. Keiser O, Anastos K, Schechter M, Balestre E, Boulle A, ART-LINC Collaboration of the International Databases to Evaluate AIDS (leDEA), et al: Antiretroviral therapy in resource-limited settings 1996 to 2006: patient characteristics, treatment regimens and monitoring in sub-Saharan Africa, Asia and Latin America. Trop Med Int Health 2008, 13(7):870-879.

25. Deblonde J, De Koker $\mathrm{P}$, Hamers FF, Fontaine J, Luchters S, Temmerman M: Barriers to HIV testing in Europe: a systematic review. Eur J Public Health 2010, 20(4):422-432.

26. Carrizosa CM, Blumberg EJ, Melbourne FH, Martinez-Donate AP, GarciaGonzales G, Lozada R, et al. Determinants and Prevalence of late HIV testing in Tijuana, Mexico. AIDS Patient Care and STDs 2010; 24(5). DOI: $10.1089=$ apc. 2009.0138

27. Kalichman SC, Simbayi LC: HIV testing attitudes, AIDS stigma, and voluntary HIV counselling and testing in a black township in Cape Town, South Africa. Sex Transm Infect 2003, 79(6):442-447.

28. Burns FM, Johnson AM, Nazroo J, Ainsworth J, Anderson J, Fakoya A, et al: Missed opportunities for earlier HIV diagnosis within primary and secondary healthcare settings in the UK. AIDS 2008, 22(1):115-122.

29. Reed JB, Hanson D, McNaghten AD, Bertolli J, Teshale E, Gardner L, et al: HIV testing factors associated with delayed entry into HIV medical care among HIV-infected persons from eighteen states, United States, 20002004. AIDS Patient Care STDs 2009, 23(9):765-773.

30. Burke RC, Sepkowitz KA, Bernstein KT, Karpati AM, Myers JE, Tsoi BW, et al: Why don't physicians test for HIV? A review of the US literature. AIDS 2007, 21:1617-1624.

31. Antinori A, Coenen T, Costagiola D, Dedes N, Ellefson M, Gatell J, et al: Late presentation of HIV infection: a consensus definition. HIV Medicine 2011, 12:61-64.

32. Thanawuth N, Chongsuvivatwong V: Late HIV diagnosis and delay in CD4 count measurement among HIV-infected patients in Southern Thailand. AIDS Care 2008, 20(1):43-50.

33. Fernandes JRM, Acurcio FA, Campos LN, Guimarães: Início da terapia antiretroviral em estágio avançado de imunodeficiência entre indivíduos portadores de HIV/AIDS em Belo Horizonte, Minas Gerais, Brasil [Initiation of antiretroviral therapy in HIV-infected patients with severe immunodeficiency in Belo Horizonte, Minas Gerais State, Brazil]. Cad Saúde Pública = Rep. Public Health 2009, 25(6):1369-1380.

34. Souza-Jr PR, Szwarcwald CL, Castilho EA: Delay introducing antiretroviral therapy in patients infected by HIV in Brazil, 2003-2006. Clinics (São Paulo) 2007, 62(5):579-584

35. Lucena FFA, Fonseca MGP, Sousa AIA, Coeli CM: O relacionamento de bancos de dados na implementação da vigilância da AIDS. Relacionamento de dados e vigilância da AIDS [Applying record linkage in AIDS surveillance]. Cad Saúde Colet (Rio J.) 2006, 14(2):305-312.
36. Grangeiro A, Escuder MM, Castilho EA: Magnitude and trend of the AIDS epidemic in Brazilian cities, from 2002 to 2006. Rev Saude Publica 2010, 44 (3):430-440

37. Ministério da Saúde, Secretaria de Vigilância em Saúde, Departamento Nacional de DST, Aids e Hepatites Virais. Boletim Epidemiológico Aids-DST. Brasília: 2011; Ano VIII, No. 1. Available from: http://www.aids.gov.br/ publicacao/2011/boletim_epidemiologico_2011. Accessed in 2011 (Dez 20)

38. Nhac-Vu H-T, Giard M, Phong N-D, Vanhems P: Risk factors for delayed HIV diagnosis at the hospital of tropical diseases in Ho Chi Minh City, Vietnam. International Journal of STD \& AIDS 2010, 21:802-805.

39. França Junior I, Calazans G, Zucchi EM: Grupo de Estudos em População, Sexualidade e Aids. Mudanças no âmbito da testagem anti-HIV no Brasil entre 1998 e 2005 [Change in HIV testing in Brazil between 1998 and 2005]. Rev Saude Publica 2008, 42(1):84-97.

40. Brazilian Ministry of Health. Health Surveillance Secretariat. National Programme STD and AIDS. Targets and Commitments made by the Member-States at the United Nation General Assembly Special Session on HIV/AIDS. UNGASS - HIV/AIDS. Brazilian Response: 2005/2007. Country Progress Report. Brasília: National Programme STD and AIDS; 2008. Available from: http://data.unaids.org/pub/report/2008/ brazil_2008_country_progress_report_en.pdf. Accessed in 2011 (May 11).

41. Sanders GD, Bayoumi AM, Sundaram V, Bilir SP, Neukermans CP, Rydzak CE, et al: Cost-effectiveness of screening for HIV in the era of highly active antiretroviral therapy. N Engl J Med 2005, 352:570-585.

42. Tole SP, Sanders GD, Bayoumi AM, Galvin CM, Vinichenko TN, Brandeau ML, et al: Cost-effectiveness of voluntary HIV screening in Russia. Int J STD AIDS 2009, 20(1):46-51.

43. Severe P, Juste MA, Ambroise A, Eliacin L, Marchand C, Apollon S, et al: Early versus standard antiretroviral therapy for HIV-infected adults in Haiti. N Engl J Med 2010, 363(3):257-265.

44. Siegfried N, Uthman OA, Rutherford GW. Optimal time for initiation of antiretroviral therapy in asymptomatic, HIV-infected, treatment-naive adults. Cochrane Database Syst Rev 2010; (3):CD008272.

45. Dodd PJ, Garnett GP, Hallett TB: Examining the promise of HIV elimination by 'test and treat' in hyper-endemic settings. AIDS 2010, 24(5):729-735.

doi:10.1186/1471-2334-12-99

Cite this article as: Grangeiro et al:: Late entry into HIV care: lessons from Brazil, 2003 to 2006. BMC Infectious Diseases 2012 12:99.

\section{Submit your next manuscript to BioMed Central and take full advantage of:}

- Convenient online submission

- Thorough peer review

- No space constraints or color figure charges

- Immediate publication on acceptance

- Inclusion in PubMed, CAS, Scopus and Google Scholar

- Research which is freely available for redistribution 